\title{
SCREENING AND REGISTERING PATIENTS WITH ASTHMA AND COPD IN SLOVENIAN PRIMARY CARE: FIRST RESULTS PRESEJANJE IN REGISTRIRANJE BOLNIKOV Z ASTMO IN KOPB V REFERENČNIH AMBULANTAH DRUŽINSKE MEDICINE: PRVI REZULTATI
}

\author{
Tonka POPLAS-SUSIČ ${ }^{1}$, Igor ŠVAB² ${ }^{2}$ Darinka KLANČAR², Davorina PETEK², \\ Vlasta VODOPIVEC-JAMŠEK ${ }^{2}$, Mateja BULC ${ }^{2}$, Janko KERSNIK², Beáta Éva PETROVSKI ${ }^{3^{*}}$
}

\author{
${ }^{1}$ Community Health Centre Ljubljana, Metelkova 9, 1000 Ljubljana, Slovenia \\ ${ }^{2}$ University of Ljubljana, Medical Faculty, Department of Family Medicine, Poljanski nasip 58, 1000 Ljubljana, Slovenia \\ ${ }^{3}$ University of Szeged, Department of of Public Health, Faculty of Medicine, Dóm tér. 10, Szeged, 6720, Hungary
}

\section{ABSTRACT}

Keywords: primary health care, model practices, family practice, nurse practitioner, asthma, COPD, Slovenia

\begin{abstract}
Aim. This study aimed to evaluate a new project of the Slovene Ministry of Health - the Family Medicine Model Practices (MPs) Project in Slovenia, and to show its effectiveness in the management of asthma and COPD by family medicine practice teams, consisting of a family physician, a nurse practitioner and a practice nurse.

Methods. A total of 107 family practices with 203122 patients joined the project during the first year of its initiation. The effectiveness of the program in disease management was analysed in two phases according to the registration of family practices. The number of patients registered and the number of asthma and COPD patients (existing and newly detected) by model practice teams were being reported. Descriptive analyses were used to describe the study populations. Prevalence by diseases and phases was established after the initial round of data collection. Chi square $\left(\mathrm{x}^{2}\right)$ test was used to analyse the difference between the phases.
\end{abstract}

Results. The frequency of asthma was $2.12 \%$, while the frequency of COPD was $1.15 \%$ throughout the study period. For both diseases, more than $30 \%$ of patients were newly diagnosed.

Conclusions. The project of implementing Family Medicine MPs in the area of COPD has given first positive results and the project is still ongoing to its full implementation.

Uvod. Namen študije je predstaviti projekt Ministrstva za zdravje, referenčne ambulante, ki poteka $v$ Sloveniji, in prikazati rezultate obravnave bolnikov $z$ astmo in KOPB s strani tima, ki je dopolnjen in ga sestavljajo zdravnik, diplomirana medicinska sestra in zdravstveni tehnik.

Metode. $V$ prvem letu je bilo $v$ projekt vključenih 107 ambulant z 203.122 opredeljenimi pacienti (glavarina). Uspešnost programa obravnave pacientov je bila analizirana dvofazno, ob prvi in naslednji $v k l j u c ̌ i t v i$ ambulant $v$ projekt. Vse referenčne ambulante so poročale o številu opredeljenih bolnikov (glavarina) in o številu bolnikov z astmo in KOPB (že obstoječih in med presejanjem novo odkritih bolnikov). Deskriptivna analiza je bila uporabljena za opis obravnavane populacije. Prevalenca po boleznih je bila prikazana ločeno $v$ prvi in drugi fazi analize. Test hi-kvadrat je prikazal razlike med obema fazama raziskave.

Rezultati. Vopazovanem obdobju je bila pogostnost astme med opazovano populacijo 2,12\%, pogostnost KOPB pa 1,15\%. Tako med bolniki z astmo kot med bolniki s KOPB je bila bolezen novo odkrita pri več kot $30 \%$ bolnikov.

Zaključek. Projekt implementacije referenčnih ambulant, ki je še v razvoju, je na področju obravnave bolnikov $s$ KOPB in astmo pokazal prve pozitivne rezultate.

*Corresponding author: Tel: +367 039580 21; E-mail: petrovski.beata.eva@med.u-szeged.hu; beapepo@yahoo.com 


\section{INTRODUCTION}

The diseases of the respiratory system are an important public health burden. They present the third most common cause of death in Slovenia, where $6.0 \%$ of the population has been reported to suffer from asthma (1). Hospitalisations from these diseases have been increasing since 2003 and 2009. Only limited data exist regarding their prevalence in the population and in primary care, where most of these cases are being treated (1). Among the respiratory diseases, the chronic diseases of the respiratory system are particularly important.

Previous studies have reported that many patients with asthma and COPD (Chronic Obstructive Pulmonary Disease) remain uncontrolled or not adequately controlled $(2,3)$. Although the management of non-communicable chronic diseases has become one of the most important tasks of primary care, it is generally seen that their management in this setting does not fulfil its full potential. There are many reasons for that, one of the more important ones is inadequate organisation of services, where doctors still take on the vast majority of patient care, which leads to increasing workload of the family physicians (4).

Slovenia has a health care system where primary care is largely organised around public non-for-profit health centres (5). A typical family practice team in Slovenia consisted of a family practitioner and a practice nurse with a bachelor degree (6). This system has remained relatively unchanged for a long period and, lately, there have been calls that a change is necessary. An additional problem is that the number of primary care teams and family physicians has not changed significantly in the last two decades, leaving the country well below the European Union 27 Member States (EU 27) average (7), in spite of a growing number of elderly population. Management of non-communicable chronic diseases has gone through fundamental changes resulting in different disease management programmes all over the world. One of the possible solutions to this challenge can be a change in the composition of the teams, especially by introduction of higher trained nurses - nurse practitioners (NPs). Instead of screening only for cardio-vascular diseases (CVD), an introduction of screening for several non-communicable chronic diseases (NCD) for people aged 30 and olderhas been implemented. Therefore, a development of registers of chronic diseases started at the same time.

There is ample evidence proving that involvement of multidisciplinary teams decreases the workload of family physicians without compromising the quality of care (8). NPs have a unique position as frontline caregivers and patient educators in recognizing, assessing and effectively treating the widespread problem of uncontrolled diseases (9), and supplement for the care provided by thefamily practitioners (10). They can undertake much of the health promotion workload of the family physicians and have a leading role in the routine management of adequately treated chronic diseases (10).

The aim of this study was to assess the programme of Family Medicine MPs in Slovenia, which was developed along the above-mentioned principles, and to describe the recruitment of patients with asthma and COPD in the project.

\section{METHODS}

\subsection{Setting}

The Family Medicine MPs program was introduced by the Slovenian Ministry of Health with the aim of improving the management of chronic diseases, including asthma and COPD in primary care by introducing NPs as new members of the team. Their tasks included prevention in patients aged 30 and older, and routine management of all registered patients with stable chronic diseases.

The team was thus extended by 0.5 full-time equivalent (FTE) nurse (11). The project was initiated in 2011. Every team had to make a registry of asthma and COPD cases in their practice and to manage these diseases according to a detailed protocol (12), based upon clinical evidence agreed between experts in family medicine, clinicians and nurses. The role of nurses in asthma and COPD was to create a registry of these patients and to manage the stable ones according to the protocol. Following this protocol, the NPs systematically reviewed the history details by using questionnaires (e.g. Asthma Control test, COPD Assessment Test) and by posing other relevant questions. They examined the patients according to their competence, and provided education with counselling, oriented toward life-style improvement and focusing on problems related to COPD/asthma. Specifically, the NPs controlled the treatment compliance and skills for appropriate use of inhalers, the skills and results of patient Peak Expiratory Flow (PEF) measurements as well as performed spirometry.

The project was performed in accordance with the Declaration of Helsinki (1975) and was approved by the National Ethical Committee of Slovenia in September, 2012.

\subsection{Data Sources}

The data were collected from the national database that was established especially for the purpose of this project. The sources of data were obligatory reports from practices that were delivered monthly. Data collection began in June 2011. In the report, the practices had to state the number of patients registered and the number of cases (existing cases and newly detected cases during the screening of patients aged 30 years and 
older) of asthma and COPD that were identified. The study population included all those registered with the participating practices. Potential cases were patients who had been reported to have asthma and COPD by their family physicians using the ICD10 Codes. The diagnoses of asthma and COPD were based on the criteria of the World Health Organization (WHO) and were confirmed either by a clinical specialist or spirometry. The source population of the study consisted of patients registered at one of the participating 107 Model Practices (31 December 2011).

\subsection{Data Analysis}

The analysis of the initial results was implemented in two phases. The first phase included a group of MPs and cases of asthma/COPD that were detected from the beginning of the project in April 2011 (started with reports in June), until September 2011, while the second phase included those MPs that joined the project in September 2011, and lasted until December 2011. The differences noted between the two phases were registered in the data management system. The starting data were used to compare the presence of existing and newly reported cases in a 4-monthly period with the expectation that the second phase would involve better data management, since more training and experience would have accumulated during the first phase.

The statistical analysis was based on the data from June 2011, until December 2011. Simple descriptive analysis was used to describe the study populations. Prevalence sorted by diseases and phases was established after the initial round of data collection. Chi square (x2) test was used to analyse the difference between the two phases. $\mathrm{P}<0.05$ was considered statistically significant.

The tendency of the data management was investigated in two phases: those who started the project in June 2011, and those in September 2011. A comparison analysis of the data was used for the first 4 months.

\section{RESULTS}

\subsection{Study Population}

The distribution of patients and practices is shown in the Table 1. During the first phase, which began in June 2011, 60 family practices joined the project, with 114819 patients on the patient list. This number grew slightly to 116612 patients in September 2011. During the second phase, which began in September 2011, additional 47 practices joined the project. The number of patients included during this phase was 71976 , while by the end of the year 2011 it increased to 86510 patients.

A total of 107 practices with an overall 203122 subjects were included into the project during the two phases (Table 1). The frequency of MPs and patients was the highest in Zasavska/Notranjsko-Kraška/Osrednjeslovenska regions (MPs: 29.91\%; patients (Phase 1/Phase 2): 25.91/38.02\%), in the Podravska region (MPs: 16.82\%; patients (Phase1/ Phase 2): 16.50/17.56\%) and in the Gorenjska region (MPs: 14.95; patients (Phase 1/Phase 2): 13.22/18.57\%) (Table 1).

Table 1. Regional distribution of population and family practices involved in the Family Medicine Model Practices (MPs) Project in December, 2011.

\begin{tabular}{|c|c|c|c|}
\hline & \multicolumn{2}{|c|}{$\begin{array}{l}\text { Percentage and number of patients } \\
\text { in the Family Medicine MPs Project }(n=203122)\end{array}$} & \multirow[t]{2}{*}{$\begin{array}{l}\text { Percentage and number } \\
\text { of Family Medicine MPs }\end{array}$} \\
\hline & $\begin{array}{c}\text { Phase } 1 \\
(n=116612)\end{array}$ & $\begin{array}{c}\text { Phase } 2 \\
(n=86510)\end{array}$ & \\
\hline Regions & $x(\%)(n=116612)$ & $x(\%)(n=86510)$ & $x(\%)(n=107)$ \\
\hline Pomurska & $4.90 \%$ (5709) & $6.63 \%(5736)$ & $5.61 \%(6)$ \\
\hline Podravska & $16.50 \%(19252)$ & $17.56 \%(15189)$ & $16.82 \%(18)$ \\
\hline Koroska & $2.82 \%$ (3289) & NPR & $1.89 \%(2)$ \\
\hline Savinjska & $10.88 \%(12690)$ & $6.25 \%(5407)$ & $9.35 \%(10)$ \\
\hline $\begin{array}{l}\text { Zasavska } \\
\text { Notranjsko-Kraska } \\
\text { Osrednjeslovenska }\end{array}$ & $25.91 \%(30211)$ & $38.02 \%(32890)^{*}$ & $29.91 \%(32)$ \\
\hline Spodnjeposavska & $4.97 \%(5798)$ & NPR & $2.80 \%(3)$ \\
\hline Jugovzhodna Slovenija & $6.41 \%(7478)$ & $4.03 \%(3486)$ & $5.61 \%(6)$ \\
\hline Gorenjska & $13.22 \%(15415)$ & $18.57 \%(16068)$ & $14.95 \%(16)$ \\
\hline Goriska & $11.09 \%(12933)$ & $3.75 \%(3246)$ & $8.41 \%(9)$ \\
\hline Obalno-Kraska & $3.29 \%$ (3837) & $5.19 \%(4488)$ & $4.67 \%(5)$ \\
\hline
\end{tabular}

$\mathrm{n}=$ number of subjects; NPR: no patients were registered; Phase 1: four-month period, from June until September 2011; Phase 2: four-month period, from September until December 2011. *No patients were registered from the Zasavska region. 


\subsection{Prevalence of Asthma and COPD}

The number of registered patients with asthma increased in the first phase. Among those who started the project in June 2011 , it increased from $1.62 \%$ (1855 persons) to $2.15 \%$ (2512 persons) by September 2011. Out of them, 1.99\% (2307 persons) had already confirmed asthma (prevalent cases), while in $0.16 \%$ (205 patients) the condition was newly diagnosed in September 2011. The frequency of the latter patients showed a decreasing tendency from $0.22 \%$ ( 265 persons) in July 2011 , to $0.16 \%$ ( 205 persons) in September 2011. In the first three-month period, a total of 2512 persons were reported to have asthma, out of which 657 persons $(26.15 \%)$ were newly diagnosed.

In the second phase of the project, the frequency of registered asthma patients continued to grow from 1.52\% (1093 persons) in September 2011, to 2.09\% (1803 persons) in December 2011. Out of them, 1.89\% (1569 persons) had been diagnosed previously in December 2011, while 0.20\% (234 persons) were newly diagnosed. The frequency of the latter patients was $0.24 \%$ (315 persons) in October 2011, and then it decreased to $0.13 \%$ (161 persons) in November 2011 , only to increase again to $0.20 \%$ (234 persons) in December 2011. Altogether, 1803 persons were reported of having asthma in the second three-month period, out of which 710 persons $(39.38 \%$ ) were newly diagnosed. There were no significant differences based upon the growth of registered patients in the two phases $(\mathrm{P}=0.9)$ (Figures 1 , $3,4)$.

Phase 1
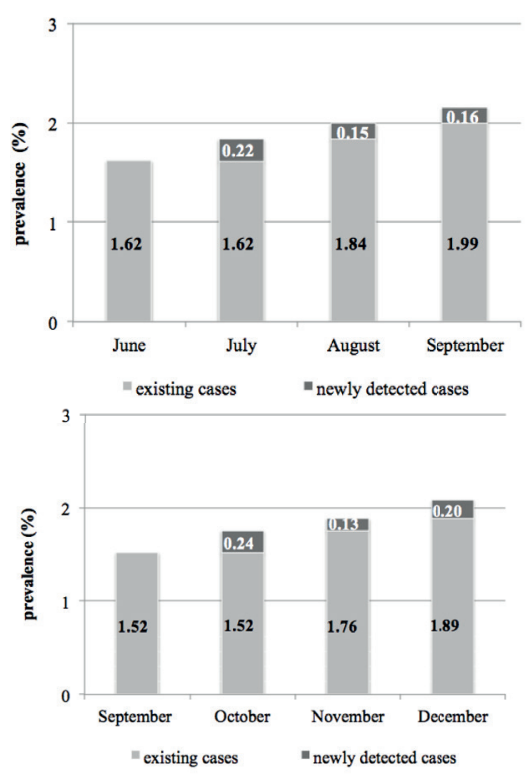

Figure 1. The frequency of the existing and newly detected asthma in the two phases of the study*.

*There were no significant differences based upon the growth of registered patients in the two phases $(P=0.9)$.

Phase 1: A four-month period, from June until September 2011.

Phase 2: A four-month period, from September until December 2011
The number of patients registered as COPD in the first phase (those who started the project in June 2011), showed an increasing tendency from $0.88 \%$ (1006 persons) at the beginning, to $1.19 \%$ (1383 persons) in September 2011. Out of them, $1.09 \%$ (1261 persons) had been diagnosed previously, while $0.10 \%$ (122 persons) were newly diagnosed. The frequency of the latter showed a decreasing tendency in the first three-month period, from $0.13 \%$ (160 persons) in July 2011 to $0.10 \%$ (122 persons) in September 2011. Altogether, 1383 persons were reported of having COPD in the first phase, out of which 377 persons $(27.26 \%)$ were newly diagnosed. In the second phase of the study, the frequency of COPD also followed an increasing tendency from $0.78 \%$ ( 558 persons) at the beginning to $1.11 \%$ (963 persons) in December 2011. Out of them, $1.05 \%$ (879 persons) had been diagnosed previously, while $0.06 \%$ (84 persons) was newly diagnosed. The frequency of the latter showed a decreasing tendency from $0.16 \%$ (191 persons) in October 2011 to $0.06 \%$ (84 persons) in December 2011. Altogether, 963 persons were reported of having a disease in the second phase, out of them 405 persons $(42.06 \%)$ were newly diagnosed. There were no significant differences between the two phases $(P=0.9)$ (Figures 2, 3, 4).

Phase 1

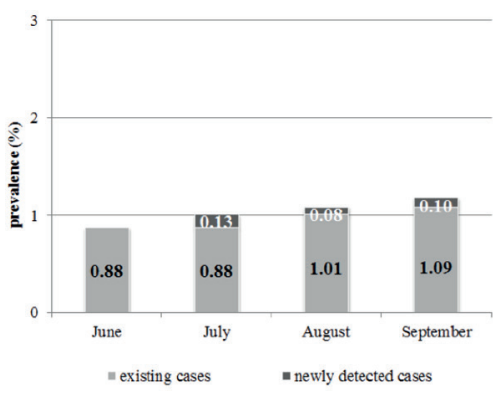

Phase 2

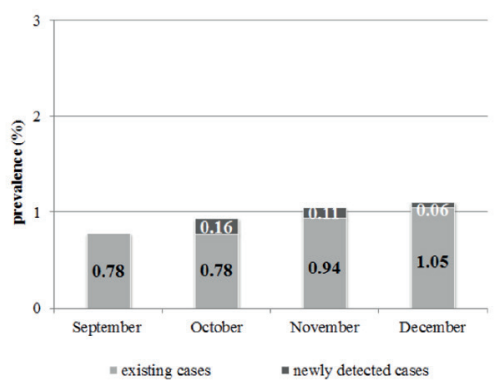

Figure 2. The frequency of the existing and newly detected COPD in the two phases of the study**.

**There were no significant differences between the two phases $(P=0.9)$.

Phase 1: A four-month period, from June until September 2011.

Phase 2: A four-month period, from September until December 2011. 
In both phases, a total of 4315 persons (2.12\%) were reported of having asthma in the four-month study period, out of which 1367 persons (31.68\%) were newly diagnosed. Similarly for COPD, a total of 2346 persons (1.15\%) were reported of having the disease in the same observational period, out of which 782 persons (33.33\%) were newly diagnosed (Figure 4). Overall, there was a relatively high proportion of newly diagnosed cases (more than $30 \%$ for both diseases).
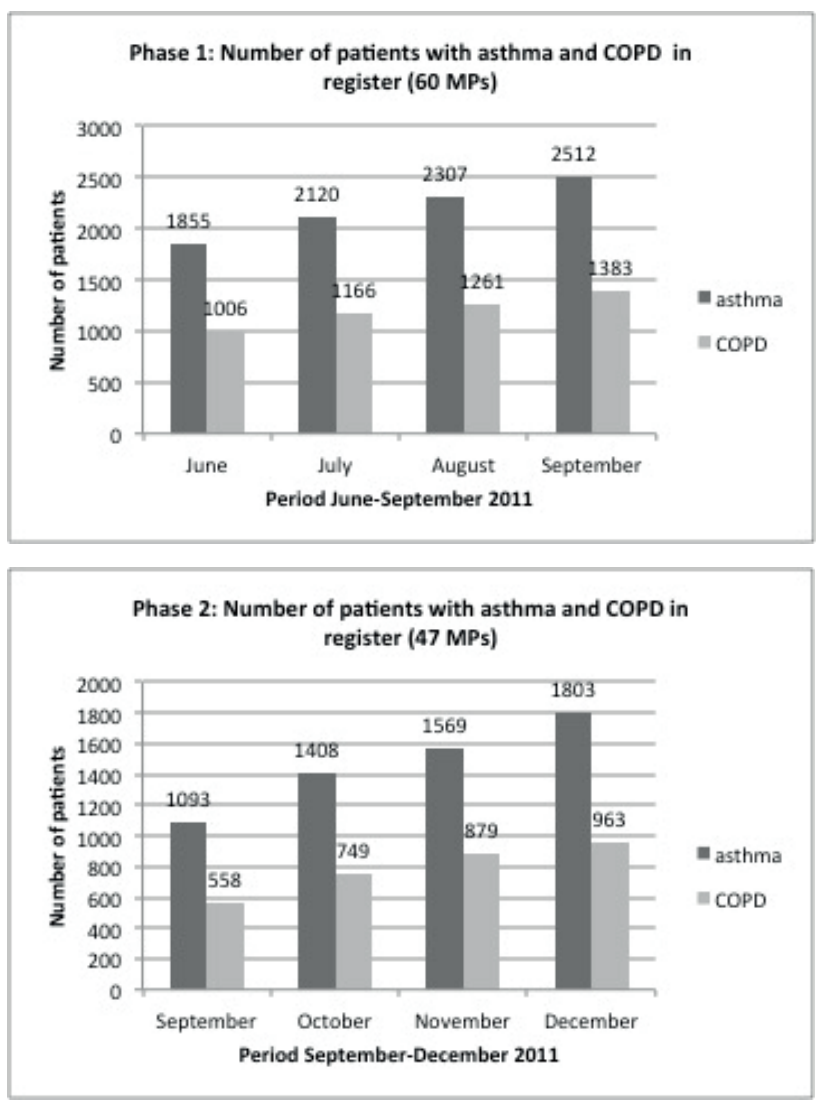

Figure 3. The number of patients with asthma and COPD in the register in Phase 1 and Phase 2.

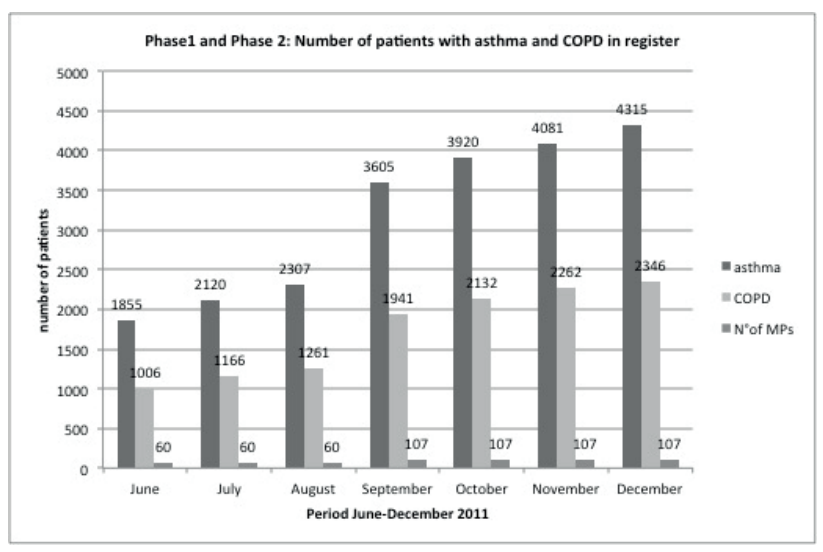

Figure 4. A total number of patients with asthma and COPD in the register.

\section{DISCUSSION}

In the first and second phase of introducing Family Medicine MPs, the physicians were highly motivated and wanted to improve or upgrade the patients' care. The NPs were also very interested to contribute to the teamwork, because they found new challenges in family medicine which they had not experienced before. Probably, these are the reasons for a rather intensive screening and registering of patients with asthma and COPD in the very first month, in which the NPs wanted to present their role as important. Patients in the registers have to be managed according to the protocols (exactly defined measures, frequencies of visits and way of treatment).

Although we expected more experienced teams and better data management in the second phase of the project, this turned out not to be possible. There was no transfer of experience to the new teams from the previously included ones, probably due to geographical dispersal and allocation of practices and a short duration of the project. Therefore, more training and experience could have been accumulated and disseminated to the new MPs after the analysis of the data performed regularly at the end of each year.

The advantage of this simple methodology is to enable the gathering of data regarding the prevalence of asthma/ COPD, and to establish an epidemiological overview that can result in achieving organised public approach. The disadvantage of the methodology is not being able to follow the different indicators of chronic illnesses that are tracked and followed for every individual patient.

The regional distribution of the population and practices involved in the Family Medicine MPs project resembles the distribution of risk factors in Slovene primary health care attenders (13). The highest percentage and number of patients visiting MPs, as well as the highest number of MPs in the last 3 years, has been in the central Slovene region (Ljubljana).

The data in this study is based on the first two groups of Family Medicine MPs established; therefore, it cannot claim to be representative of the whole country, even if the Ministry took care of an even distribution of the practices. The bias in the recruitment phase is likely to be due to the fact that MPs first had to apply for the project, and was then selected from the pool of applicants as being the most ambitious and fulfilling the inclusion criteria of achieved quality of care. Nevertheless, the regional distribution of practices was well-balanced.

The prevalence of asthma in the analysed (four month) periods was around $2 \%$ in the two phases. According to the OECD report, the self-reported asthma in 2008 in the population aged 15 and older, was around 3.5\% in Slovenia (14), while in the computer assisted survey, $6.0 \%$ 
of citizens reported asthma (1), but the World Health Survey, performed between 2002 and2003, reported the prevalence of self-reported doctor-diagnosed asthma of around $8.7 \%(15)$. The prevalence of the existing COPD was around 1\% in the study period. The OECD 2012 report, in this case, described the prevalence of self-reported COPD in 2008 in the population aged 15 and older, of around $3.1 \%$ in Slovenia (14). The frequency of asthma and COPD in both phases of our study had a slowly increasing trend. There were no significant differences between the two groups based upon the data management and registration.

The most important finding in this study is that the introduction of new Family Medicine MPs resulted in the identification of chronically ill patients and management of these patients by standard protocols (a structured way of patients' treatment) (12), which were followed in 4315 patients with asthma and 2346 patients with COPD (Figure 4). This is a strong message to policy makers to continue with the project, which will eventually end up introducing NPs in every family practice within the next 4 years. Although a survey of satisfaction of patients was not a part of this study, the project is supported by high levels of patient satisfaction with NPs, where a mean total score on the newly developed questionnaire was $87.9 \pm 12.4$ points, and the mean percentage of respondents with answers 4 or 5 on the five-point Likert scale of all items was $92.2 \%$ (16).

Another important aspect of this analysis relates to the number of undiagnosed patients, which is a serious problem in chronic disease management in primary care. Since 2002, when the National preventive program for CVD started (17-21), patients have not been screened for asthma and COPD and, after the implementation of this screening in April 2011, more and more patients were identified, so the number of patients with these two diseases has been continuously growing. Moreover, protocols (12) for the management of patients with asthma/COPD have been introduced, and they improved the process of care. We could demonstrate that there was a relatively high percentage of newly diagnosed or previously non-identified patients in both phases and diseases, which was around $30 \%$. Partly, this could be due to unconfirmed existing working diagnosis for asthma/ COPD in the past (22-24). In a study done in Poland, this percentage for COPD was even higher (almost 50\%) (25); in a country with a well-established primary care, the proportion was similar (26).

We could also show some geographical inequality in the distribution of these patients, similar to the distribution in the 'Register of high-risk patients for cardiovascular disease.' This may reflect the well-known East-West gradient of health inequalities in the country. In the Register of lifestyle risk factors from January 2002 until September2009, the most harmful alcohol drinking was presented in Murska Sobota region and the lowest rate of physical activity (less than once per week) was stated by people in Maribor region. The prevalence of $\mathrm{BMI}>25 \mathrm{~kg} / \mathrm{m}^{2}$, hypertension and hypercholesterolemia, were the highest in Krško region. In the results of the National preventive program for CVD started in year 2001, Ljubljana region had low prevalence of risk factors for chronic non-communicable diseases, indicating the preventive orientation of the capital.

On the other hand, the inequalities in health care remained the same for nearly 20 years: the Eastern parts of Slovenia always had higher prevalence of risk factors and chronic diseases compared to the South-Western parts of the country (13). This aspect of the study clearly sends an important message that by introducing a systematic approach to primary care, the level of medical care improves (23, 21).

An increase in the number of Family Medicine MPs resulted, as expected, in an increase in the number of patients diagnosed with asthma and COPD. The results are somewhat expected since they come from the implementation of a systematic screening approach which included more and more patients among a growing number of capitations in MPs.

\section{CONCLUSIONS}

The implementation of Family Medicine MPs in Slovenia represents new challenges in the task distribution within the primary care team, which is expanded with a nurse practitioner. The number of patients with asthma/ COPD will probably rise in the next months because new patients will be involved in the permanent screening. After the screening of the patients included in the study, the prevalence of asthma/COPD will become steady, and for the first time, the epidemiological data on asthma/ COPD will be known.

So far, we can only presume that the quality of treatment of patients with asthma and COPD in MPs is better because it is more systematic than in other family practices. Various quality indicators have been developed and will be collected within the protocols of disease management. The data from the disease management protocols has not been systematically collected on the national level yet, so we still wait for the ultimate proof of clinical quality improvement.

Overall, it is obvious that the project of implementing Family Medicine MPs in the area of chronic respiratory diseases already shows positive results; the project is an on-going one, but still far from its full implementation. 


\section{ACKNOWLEDGMENTS}

The authors would like to thank the family physicians and nurse practitioners for their contribution to the study. Also, we are grateful to all study participants for their kind co-operation in the examinations and reports. The authors would also like to thank the staff at the Ministry of Health and Project Office 'Prava Poteza' for their contribution.

\section{CONFLICTS OF INTEREST}

Our research represents original, unpublished material. It does not overlap or duplicate other manuscripts that are under review, in press or published. We have not submitted this manuscript elsewhere for publication. We have no financial or other contractual agreements that might cause conflicts of interest, or be perceived as discoursing conflicts of interest. There are no company products associated with this research; hence, there are no existing financial arrangements between any of the authors and a company.

\section{FUNDING}

None.

\section{ETHICAL APPROVAL}

Not required.

\section{AUTHORS' CONTRIBUTION}

IS oversaw the design of the study, BEP analysed the data. All authors were involved in the development of the project, study design, data collection and its interpretation. All authors contributed to the preparation of the manuscript and approved the final version of the text.

\section{REFERENCES}

1. Suskovic S, Gril M, Hudoklin I, Klobucar A, Koren I, Koterle M. et al. Prevalence of asthma in adults in Slovenia. Zdrav Vestn 2011; 80: 451-7.

2. Chapman KR, Boulet LP, Rea RM, Franssen E. Suboptimal asthma control: prevalence, detection and consequences in general practice. Eur Respir J 2008; 31: 320-5.

3. Peters SP, Jones CA, Haselkorn T, Mink DR, Valacer DJ, Weiss ST. Realworld Evaluation of Asthma Control and Treatment (REACT): findings from a national Web-based survey. J Allergy Clin Immunol 2007; 119: 1454-61.

4. Darker C, Martin C, O’Dowd T, O’Kelly F, O'Shea B. Chronic disease management in general practice: results from a national study. Ir Med J 105: 102-5.
5. Klančar D, Kersnik, J. Vizija prihodnosti zdravstvenih domov v Sloveniji. Zdrav Var 2010; 49: 37-43.

6. Oleszczyk M, Svab I, Seifert B, Krzton-Krolewiecka A, Windak A. Family medicine in post-communist Europe needs a boost: exploring the position of family medicine in healthcare systems of Central and Eastern Europe and Russia. BMC Fam Pract 2012; 13: 1-10.

7. Health for all database, version January 2013. Copenhagaen: WHO Regional Office for Europe, 2013. Available Jan 10, 2013 from: data. euro.who.int/hfadb/

8. Bodenheimer T, Chen E, Bennett HD. Confronting the growing burden of chronic disease: can the U.S. health care workforce do the job? Health Aff (Millwood) 2009; 28: 64-74.

9. Rance KS. Helping patients attain and maintain asthma control: reviewing the role of the nurse practitioner. J Multidiscip Healthc 2011; 4: 299-309.

10. Laurant MG, Hermens RP, Braspenning JC, Sibbald B, Grol RP. Impact of nurse practitioners on workload of general practitioners: randomised controlled trial. BMJ 2004; 328: 927.

11. Poplas-Susic T. Referential outpatient units. Bilt Ekon Org Infor Zdrav 2011; 27: 9-17.

12. Vodopivec Jamšek V. Protokol za vodenje kroničnega bolnika v referenčni ambulanti družinske medicine. Zdrav Vest 2013; 82: 711-7.

13. Fras Z. Zgodba o uspehu ali kako smo lahko še boljši. In: Slovenski forum za preventivo bolezni srca in žilja: zbornik prispevkov. Ljubljana: Združenje kardiologov Slovenije, 2012: 10-30.

14. OECD. Health at a glance: Europe 2012. Paris: OECD, 2012.

15. To T, Stanojevic S, Moores G, Gershon AS, Bateman ED, Cruz AA. et al. Global asthma prevalence in adults: findings from the cross-sectional world health survey. BMC Public Health 2012; 12: 204.

16. Klemenc-Ketiš Z, Poplas-Susič T, Švab I, Kersnik J. New tool for patient evaluation of nurse practitioner in primary care settings. J Clin Nurs 2014; 23: 1323-31.

17. Brotons C, Bulc M. et al. Prevention and health promotion in clinical practice : the views of general practitioners in Europe. Preventive medicine 2005; 40: 595-601.

18. Bulc M. Primarna preventiva srčno-žilnih bolezni. In: Kersnik J, editor. V. Fajdigovi dnevi. Gerb, astma, migrena, hiperlipodemija, alergija: zbornik predavanj. Ljubljana: Združenje zdravnikov družinske medicine SZD, 2003: 85-9.

19. Bulc M. Dokazi za odkrivanje, zdravljenje in vodenje kroničnih bolezni. In: Kersnik J, editor. Znanstveno utemeljena medicina. Ljubljana: Združenje zdravnikov družinske medicine SZD, 2000: 107-13.

20. Klemenc-Ketiš Z, Bulc M, Kersnik J. Attitudes of Slovenian family practice patients toward changing unhealthy lifestyle and the role of family physicians: cross-sectional study. Croat Med J 2011; 52: 205-11.

21. Bulc M. Prvih pet let preventivnih pregledov odrasle populacije - kaj smo se naučili? In: Kert S, Tušek-Bunc K, editors. Dermatologija, ORL, gastroenterologija, psihiatrija, postopki na ZK in IK, kronična bolečina: zbornik. Družinska Med 2008; 6(Suppl 5): 96-9.

22. Walker PP, Mitchell P, Diamantea F, Warburton CJ, Davies L. Effect of primary-care spirometry on the diagnosis and management of COPD. Eur Respir J 2006; 28: 945-52.

23. Abramson MJ, Shattner R, Sulaiman ND. et al. Do spirometry and regular follow-up improve health outcomes in general practice patients with astma od COPD?: a cluster randomised controlled trial. MJA 2010; 193: 104-9.

24. Chapman KR, Boulet LP, Rea RM, Franssen E. Suboptimal astma control: prevalence, detection and consequences in general practice. Eur Respir J 2008; 31: 320-5.

25. Bednarek M, Maciejewski J, Wozniak M, Kuca P, Zielinski J. Prevalence, severity and underdiagnosis of COPD in the primary care setting. Thorax 2008; 63: 402-7.

26. Vandevoorde J, Verbanck S, Gijssels L, Schuermans D, Devroey D, De Backer J. et al. Early detection of COPD: a case finding study in general practice. Respir Med 2007; 101: 525-30. 